has evolved from the use, by primitive man, of caves as shelters, while the other has evolved from tree shelters. Other papers read before the general meeting were "Inheritance by Labile Genes", by A. Ernst ; "The Sting of the Bee", by M. Roch; "Ontogenesis of the Bird as a Problem in Evolution", by A. Portmann. These papers are all printed in full. In addition, abstracts are given of some 150 more specialized papers, dealing with nearly all branches of science, which were presented to the sectional meetings of the Society.

\section{Royal Cornwall Polytechnic Society}

THE one hundred and third annual report of the Royal Cornwall Polytechnic Society, besides containing the usual list of members, financial statements and an account of the work of the Falmouth Observatory, has several contributions of general interest. One of these is by Miss R. Beckett, who, in a paper on "Public Library Service", traces the growth of public libraries due to the Library Acts of 1850, 1855 and 1919. The Act of 1850 limited the rate to be levied to $\frac{1}{2} d$. in the $£$ and that of 185.5 to $1 d$. These sums proved quite inadequate, but it was not until 1919 that the penny rate limitation was abolished. In practice to-day, the average expenditure is $1 s, 4 d$. per head of population, though some authorities expend as much as $2 s .6 d$. In another contribution, Mr. S. Furze deals at length with the operations involved and the machinery used in tin dressing, while in a third, Mr. J. H. Rowe gives the early history of Hayle Foundry, which was founded by John Harvey (1730-1803) and developed by his son Henry Harvey (1775-1850). This foundry was the earliest in Cornwall, and became ultimately the most important engineering works in the west of England. The well-known engineer Arthur Woolf (1766-1837), the pioneer of the compound steam engine, was at one time superintendent of this works, and it was there that he built some of the finest Cornish pumping engines of the time. The history of the Royal Cornwall Polytechnic Society inevitably recalls the Fox family, and the report has a tribute to Mr. Wilson Lloyd Fox, who died on February 10, 1936. He gained one of the Society's prizes in 1860 , became a member in 1865, served as president in 1922-24, and was secretary of the Committee of the Falmouth Observatory from 1877 until 1931.

\section{Intelligence, Character-training and Civilization}

A Ludwig Mond Lecture entitled "Intelligence and Civilization", delivered at the University of Manchester last October by Prof. G. H. Thomson, of the University of Edinburgh, has been published in the first issue of the new Journal of the University of Manchester. After a preliminary discussion of some aspects of recent researches in the field of intelligence measurements, Prof. Thomson proclaims his belief (which was also H. T. Buckle's) that the history of the advance of civilization has been the history of the conquest of the world by intelligence. $\mathrm{He}$ preaches the salvaging of civilization "through the cultivation by an education proper to each of the intelligence of all". Of character-training he is profoundly distrustful. A clear vision of truth is, he assumes, to be attained solely through cultivation of the intelligence and "the schoolmaster's sole business is to lead his pupils to see truth clearly ... and ... that is the only character-training the school may lend itself to, if it is to refrain from serving party or class ... . but is to serve civilization". He does not think much of civilization's debt to the poets ("far more dangerous than scientists"), notwithstanding that he holds intelligence to be based on imagination, and he makes a point of registering disagreement with Earl Baldwin's hope, confided to the Congress of Universities of the Empire, that from those universities may presently come forth "poets who will inspire Europe and the world once more with a sense of unity and a sense of freedom".

\section{The Utilization of Wood as Fuel for Motive Power}

IN the Bulletin of the 'Société d'encouragement, pour l'Industrie Nationale' of January is printed an abstract of a paper by $R$. Vaultrin on the utilization of wood as fuel for motive power. Towards the end of the Great War, the French Ministry of Inven. tions made experiments on carrying heavy loads between Paris and Rouen by motor-lorries provided with suitable gas generators using wood for fuel, but the results obtained were not good. In 1928, after a further rally with 'camions à gazogène', the problem was completely solved; but at that time the price of the wood fuel was too high to make it profit. able. A notable rally was made in 1930 between Paris and Rome, crossing the Alps and the Apennines, and another was made through the Iandes where resinous fuel was used and found suitable. Recent results for tourist vehicles gave 50 miles per hour consuming about $70 \mathrm{lb}$. of firewood, costing six francs for a sixty miles run. Heavy motor-lorries can run at 30 miles per hour, the cost for sixty miles being fifteen francs. In France, there is an annual overproduction of thirteen million cubic yards of firewood. This would be sufficient for 60,000 motor-vehicles using gas generators. At the moment, the difficulty is to obtain, on the road, supplies of suitable wood with constant humidity. This double problem has been solved between Frankfort and Cologne. In France there are already large stores on a 'national' road, and all the main routes on the east are being supplied with stores. The control of the humidity of the wood distributed is being studied.

\section{Electric Furnaces}

DURING last year the use of electricity for the melting and heat treatment of iron and steel in Great Britain considerably increased. There has been a revival in the demand for arc furnaces, a number of which, varying in capacity from 500 to 6,000 kilowatts, are being installed. In the Electrical Review of April, Mr. D. Campbell states that the furnaces ordered from a single manufacturing company during last year would consume about a 100 million electric units a year. The cost of the annual power bill for

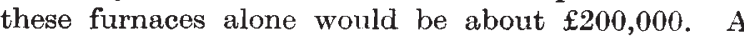

